\title{
What Are the Directions of the EU Integration Process?
}

\begin{abstract}
Just before the 2019 European Parliament (EP) elections many authors have indicated their exceptional nature. In this article the author attempts to analyze how these particular characteristics and first decisions taken after the elections by the key EU level actors may shape the EU integration process in the coming years. The article focuses on how the fragmentation of the EP may influence the choice of the European integration directions in the near future. One of the first observed effects of this fragmentation was the failure of leading candidates system during the appointment process of the Commission President. Another one is Ursula von der Leyen's political programme for the European Commission, built on the strong awareness of the need to create a governing coalition between the EP and the European Commission. Acknowledgment of the challenge of the EP diversity by the New Commission President may have a positive effect on the EU-level democracy, however with a decrease in the efficiency of the EP legislative process.
\end{abstract}

Keywords: the European Union, the European Parliament, the European Commission

\section{Introduction}

The 2019 European Parliament (EP) elections have demonstrated some distinctive features in many regards. ${ }^{1}$ First of all, it was the $40^{\text {th }}$, symbolic anniversary of the direct elections to the EP. The circumstances

\footnotetext{
^ Adriana Zabłocka-Abi Yaghi - University of Gdansk, e-mail: adriana.zablockaabi-yaghi@ug.edu.pl, ORCID: 0000-0002-8483-4517.

1 D. Fromage, The 2019 European Parliament elections: Looking back and ahead, "Perspectives on Federalism", No. 11(1)/2019, pp. 94-101.
} 
of these elections were also special in the context of ongoing Brexit. Additionally, the pre-election prediction pointed to the loss of majority by the Grand coalition that had been dominating EP for several decades. Filling five important positions in the EU (the President of the EP, the President of the European Commission, the President of the European Council, the High Representative of the Union for Foreign Affairs and Security Policy and the President of the European Central Bank) at the same time may be considered as extraordinary circumstances as well. Due to the fact that the impact of Brexit on election results can be treated as a separate issue requiring qualitative and quantitative research, this article is devoted to three other distinctive features of the last EP elections. Particular attention was paid to the fragmentation of the EP and the circumstances of the appointment of the new President of the European Commission. These factors seem to shape political guidelines of the New European Commission and directions of the EU integration process in the coming years.

\section{The Composition of the European Parliament after 2019 Elections}

The direct election of Members of European Parliament (MEPs) by EU citizens is perceived as a way for Europeans to express their opinion on European issues. Likewise, it is essential that this opinion is heard by the key EU level actors. The 2019 EP elections brought more European citizens to the polls thanks to which a satisfactory $50 \%$ turnout was achieved. One of the important messages that have been sent to those institutions is a quest for policy alternatives. ${ }^{2}$ It was demonstrated by the loss of the pro-European "Grand coalition's" forty-year domination in the EP (a loss of 67 seats at the EP). Since the first direct election to the EP, two largest party groups, the centre-right European People's Party (EPP) and the centre-left Socialists and Democrats (S\&D), have held majority at the EP. But also, according to T. Perrson, they were "a breeding ground for Eurosceptic challenger parties opposed to the system". ${ }^{3}$ A noticeable rise of political protest parties in various European countries cannot be seen merely as a matter of concern, but also as a sign of a need for redirection of European debates and actions. The election results indicate not only that traditional political elites of the EP have failed to properly address key concerns of voters (such as: economy, unemployment, immigra-

2 T. Persson, How the elections to the European parliament fell short of providing alternatives, in: Leading academics on the European elections 2019, eds. N. Bolin, K. Falasca, M. Grusell, L. Nord, Mittuniversitetet, Demicom, Sundsvall, Sverige 2019, p. 16.

${ }^{3}$ Ibidem. 
tion and climate change ${ }^{4}$ ) in their campaigns and in their actions, but also that the elites have been losing their traditional electoral base. In the case of Christian Democratic parties, it is triggered by growing secularization in Europe and the ageing of voters. The erosion of electoral base of the centre-left social democratic parties may be accounted for by the decreasing number of industrial workers and the failure to bring back a sense of security for socially-disadvantaged groups. ${ }^{5}$ However, the electoral losses of two most established Europarties have been partially counterbalanced by the increased number of ALDE representatives in the EP, one of the three oldest Europarties. Its pro-European and socially liberal programme attracted young voters, and its adverse attitude to wealth redistribution might have appealed to older voters. ${ }^{6}$ As a Renew Europe, it is the third largest political group in the EP, formed by the MEPs from the ALDE party, the European Democratic Party and the Renaissance.

The alternative course of European integration was offered by new parties and movements in numerous Member States and resulted in an unprecedented fragmentation of the EP and consequently, a shift in political balance. As T. Perrson had noticed, ${ }^{7}$ meaningful alternatives are prerequists for democracy to work and for reducing the EU democratic shortcomings.

Alternative forces increasing their presence in the EP are the Greens (23 more) and Identity and Democracy ( 37 more MEPs). The last one is a successor of Movement for Europe of Nations and Freedom, a nationalistic, eurosceptic, far-right populist group. The success of the Greens can be attributed to the continuous upward trend since the $80 \mathrm{~s}$, representing an intergenerational shift from Materialism and Survival values toward Postmaterialism and Self-Expression values as outlined by Evolutionary Modernization theory. ${ }^{8}$ The alteration encompasses not only growing

4 Spring Eurobarometer 2019, Eurobarometer Survey 91.1 of the European Parliament. A Public Opinion Monitoring Study, 2019.

5 R.F. Inglehart, P. Norris, Trump, Brexit, and the Rise of Populism: Economic HaveNots and Cultura Backlash, "HKS Faculty Research Working Paper Series" RWP 16-026, August 2016, p. 12.

6 T.G. Schminke, How different generations voted in the EU election, 3.06.2019, https://europeelects.eu/2019/06/03/how-different-generations-voted-in-the-eu-election/ (access 2.08.2019).

7 T. Persson, op. cit., p. 16.

8 R.F. Inglehart, The Silent Revolution, Princeton University Press, Princeton, NJ 1977; R.F. Inglehart, Modernization, Existential Security, and Cultural Change: Reshaping Human Motivations and Society, in: Handbook of Advanced in Culture and Psychology, Vol. 7, eds. M.J. Gelfand, Chi-Yue Chiu, Yind-Yi Hong, Oxford University Press, Oxford 2018. 
support for environmental protection, but also principal norms concerning religion, gender equality and tolerance of outgroups. Within the last 40 years a value transition has taken place in all high-income Western countries, making postmaterialists' values politically correct and gaining popularity among the more secure, better-educated and more pronounced part of the society. ${ }^{9}$ It is demonstrated by the Spring Eurobarometrer ${ }^{10}$ since combating climate change has been indicated as a matter of priority during the electoral campaign for the EP election in the richest EU countries e.g. Sweden, Netherlands, Denmark, Finland, Belgium, Luxemburg and Germany. The percentage of votes that the Greens received in those countries during $2019 \mathrm{EP}$ elections varies between 11.1 (Netherland) and 21.5 (Germany). The biggest increase of support for the Greens, while comparing the results of 2019 EP elections with those from 2014, was observed in Ireland (4.9\% in 2014 and $11.4 \%$ in 2019) and Germany (12.8\% in 2014 and $21.5 \%$ in 2019), while a decrease of support for the party group was noted in Sweden (from 19.2\% in 2014 to $11.5 \%$ in 2019) and in some New EU Member States (Slovenia, Slovakia, Malta, Estonia and Croatia).

A shift towards postmaterialistic values is also visible in Eastern European countries, especially among the youngest voters. The economic development of these countries is gradually increasing economic and physical security which fosters the adoption of Self-expression values in the society. However, due to its historical heritage and hardships of the transition period, intergenerational value change is still slow compared to Western Europe, giving Materialists advantage over Postmaterialists. ${ }^{11}$ The results of the Spring Euronarometer ${ }^{12}$ seem to confirm it. Respondents from the majority of EU10 countries (Cyprus, Latvia, Lithuania, Bulgaria, Romania and Poland) have pointed to economy and growth as a matter of priority during the electoral campaign for the EP election. The survey shows three other top priorities in other New EU Member States, namely: immigration (Malta, Hungary and Czech Republic), combating youth unemployment (Croatia and Slovenia) as well as consumer protection and food safety (Slovakia). During 2019 EP elections there were no candidates from parties belonging to the Greens in five out of eleven New EU Member States (namely in Bulgaria, Cyprus, Czech Republic, Poland and Romania) and in the other five countries the percentage of votes they received was very small (between 0.7 and 6.3 ) and lower than the percent-

\footnotetext{
9 R.F. Inglehart, Modernization, Existential Security..., op. cit.

10 Spring Eurobarometer 2019, op. cit., p. 59.

11 R.F. Inglehart, Modernization, Existential Security..., op. cit.

12 Spring Eurobarometer 2019, op. cit., p. 59.
} 
age of votes received during $2014 \mathrm{EP}$ elections. The only exemption was Lithuania where the Greens received 14,8 percentage of votes -4.6 percentage point more than during 2014 EP elections.

Electoral success of right-wing populist parties, or in general of European populism, is explained in the literature by many factors that can be divided into the supply and demand-side of politics and regulations concerning party competition. ${ }^{13}$ In the paper the emphasis was put on demand-side of elections - changes in voters' preferences, emotions and attitudes. ${ }^{14}$ It is considered to be the most common explanation, concentrating on two issues: a progressive value change and the increase of immigation, economic distress and crisis. ${ }^{15}$ According to the cultural backlash thesis, the increasing support for populists can be to a significant extent attributed to the rejection of a progressive cultural change in form of an intergenerational shift towards post-materialistic values. ${ }^{16}$ Negative response for disseminating postmaterialistic values is considered to be a source of populist support in Europe. The research results of Inglehart\&Norris indicate that supportes of populists are strongly represented among the older generation, men, the less educated, the religious and ethnic majorities in the society. According to Inglehart \& Norris, most likely these groups feel alienated among dominating, progressive society groups. ${ }^{17}$

Other studies link the rise of far-right populism with anti-immigration sentiments. ${ }^{18}$ Voters' worries concerning immigration inflow are focused on its impact on the sense of insecurity in the context of domestic factors, such as unemployment, the size of welfare state, migrants' legal status, national crime rate and also large economic and cultural differences between natives and immigrants.

Radical voting might be also explained by economic insecurity caused not only by the inflow of immigrants but also by other economic turmoils.

${ }_{13}$ R.F. Inglehart, P. Norris, op. cit., p. 9.

14 J. Rydgren, The Sociology of the Radical Right, "The Annual Review of Sociology", No. 33/2007, p. 247.

15 D. Voss, The Political Economy of European Populism: Labour Market Dualisation and Protest Voting in Germany and Spain, "LEQS Paper", No. 132/2018, p. 7; J. Rydgren, op. cit, p. 247.

${ }_{16}$ R.F. Inglehart, P. Norris, op. cit., p. 3.

17 Ibidem.

${ }_{18}$ M. Halla, A.F. Wagner, J. Zweimeuller, Immigration and Voting for the Far Right, “Journal Ofthe European Economic Association”, No. 15 (January)/2018; J. Hainmueller, M.J. Hiscox, Educated Preferences: Explaining Attitudes Toward Immigration in Europe, "International Organization", No. 61/2007. 
Accorrding to Funke et al. ${ }^{19}$ financial crises, much more than the other economic crises, result in a strong increase of right wing voters, decreasing government majorities and increasing street protests. Neo-liberal austerity measures, migration flows, globalization, rising automation and growth of the knowledge-economy, the erosion of blue-collar labor union as well as the growing power of big businesses in recent decades are perceived as causes of growing economic inequalities in Europe. The increasing support for populists is especially visible among the insecure, low-skilled, unemployed or shop floor employees, with low wages and job security. ${ }^{20}$

Among populist parties represented in the EP the only winner of 2019 elections is the far-right populist group, Identity and Democracy, mostly thanks to the strong support gained in Germany and Italy. Other populist parties lost some seats at the new EP, therefore the 2019 elections can be regarded as a general success of European populist parties.

Summing up, the results of the EP elections indicate a shift in voters' concerns that have been induced by a number of factors, such as progressive value changes and economic insecurity. The shift led to the loss of majority, traditionally held by the EPP and the $S \& D$, which decreases the efficiency of the EP legislative process. However, as noticed by Inglehart R., it may have a positive effect on the EU-level democracy by necessity of achieving majorities through cooperation with diverse participants, leading to "a more flexible system of shifting coalitions". ${ }^{21}$ The most plausible candidate for the coalition with the EP two biggest party groups is the ALDE, while the cooperation with the Greens seems less likely.

\section{The Appointment of the President of the European Commission}

Good opportunites for working out the majority just after the EP elections were the appointments of the President of Parliament and the President of the Commission. However, the elections for these posts were held in exceptional circumstances. For the first time several importanat positions in the EU had to be filled by the the European Council at the same time: the President of the Council, the President of the European Central Bank (ECB) and the High Representative of the Union for Foreign Affairs and Security Policy. Therefore, the election of the President of the Parliament was part of wider negotiations over other positions. After the

19 M. Funke, M. Schularick, Ch. Trebesch, Going to extremes: Politics after financial crises, 1870-2014, "European Economic Review", No. 88/2016.

${ }^{20}$ R.F. Inglehart, P. Norris, op. cit., p. 10.

${ }^{21}$ R.F. Inglehart, Modernization, Existential Security ..., op. cit. 
appointment by the EU's national leaders of Christine Lagarde (France) to the President of ECB, Joseph Borrell (Spain) to the High Representative of the Union for Foreign Affairs and Security Policy, Charles Michel (Belgium) to the President of the European Council and Ursula von der Leyen (Germany) to the President of the European Commission, the European Parliament has elected an Italian David-Maria Sassoli as the President of the EP. The choice made by the European Council was announced as swift and perfectly gender balanced. ${ }^{22}$ Despite such statements, the lack of appointment of Eastern Europeans to any top positions may arise controversy. One reason for this situation may be the focus of some Eastern Europeans on blocking unwanted candidates for the President of the European Commission.

A distinctive feature of an EP election, compared to a national one, is that it does not lead to a formation of a government which is committed to implementing the policies supported by voters. However, a new way of the Commission President election, introduced by art. 17(7) of the Lisbon Treaty on European Union, ${ }^{23}$ was intended to increase the democratic legitimacy of the post. Therefore, results of EP elections should be considered by the European Council while proposing the EP a candidate for the President of the European Commission. Shackelton had named this process a creation at the European level for the first time of a link between the outcome of EP elections and the head of executive office. ${ }^{24}$ The concept of art. 17(7) of the Lisbon Treaty on European Union was implemented by the EP through the introduction of leading candidates system, based on nominations of leading candidates for the President of the European Commission by the main political parties (Spitzenkandidaten process). ${ }^{25}$ For the first time the system was applied during the EP elec-

22 J. Barigazzi et al., Von der Leyen tapped to run European Commission, "Politico", 3.07.2019; https:/www.politico.eu/article/eu-european-leaders-pick-germany-defense-ministerursula-von-der-leyen-to-lead-commission-charles-michel-council/ (access 2.08.2019).

23 Treaty of European Union, art. 17(7): "Taking into account the elections to the European Parliament and after having held the appropriate consultations, the European Council, acting by a qualified majority, shall propose to the European Parliament a candidate for President of the Commission. This candidate shall be elected by the European Parliament by a majority of its component members. If he does not obtain the required majority, the European Council, acting by a qualified majority, shall within one month propose a new candidate who shall be elected by the European Parliament following the same procedure."

${ }^{24}$ M. Shackleton, The Election of the Commission President in 2014: What Does It Tell Us about Democracy in the European Union, "ISL Working Paper", No. 4/2014, p. 6.

25 T. Christiansen, After the Spitzenkandidaten: fundamental change in the EU's political system?, "West European Politics”, June 2016. 
tion in 2014, when Jean-Claude Juncker, the leading candidate of EPP, was elected the Commission President. The successful use of a new process of the Commission President appointment was perceived as another step in the course of the EP gaining power in inter-institutional struggle with the European Council. ${ }^{26}$ For the first time the candidate for the President of the European Commission was not appointed behind the closed doors of the European Council but arose from voters' preferences.

Although the Spitzenkandidaten system was an important part of panEuropean campaign in 2019, none of the nominated leading candidates has been chosen by the European Council as a formal candidate for the Commission President. Both leading candidates of two largest Europarties - Manfred Weber (EPP) and Frans Timmermans (PES) - have not been nominated by the European Council, mostly due to a strong disapproval by the Visegrad Four (Poland, Hungary, the Czech Republic and Slovakia), along with Italy. The process of appointment of an alternative candidate - Ursula von der Leyen (EPP) - to the President of the European Commission indicates a stronger position of the European Council in confronting the EP's leading candidates. According to Christiansen and Shackleton a source of weakness of two largest Europarties in interinstitutional battle between EP and the European Council concerning the appointment of the Commission President are the results of the EP elections. ${ }^{27} \mathrm{~A}$ strong position of EPP and PES after 2014 elections made it possible to force through Juncker as the Commission President in the EPP dominated European Council. The 2019 EP elections have significantly changed the arithmetic in the EP, forcing a need to build coalitions and therefore weakening the EP position towards the European Council.

\section{Political Guidelines of the New European Commission and Challenges of the EU Integration Process}

The strong awareness of the need to create a governing coalition between the EP and the European Commission seems to affect the political programme for the European Commission presented by Ursula von der Leyen. ${ }^{28}$ The pro-

${ }^{26}$ T. Christiansen, M. Shackleton, Spitzenkandidaten 2.0: From experiment to routine in European election?, in: The European Parliament Elections of 2019, eds. L. De Sio, M. Franklin, L. Russo, Luiss University Press, p. 44.

27 Ibidem, p. 50.

${ }_{28}$ A Union that strives for more. My agenda for Europe. By candidate for President of the European Commission Ursula von der Leyen. Political Guidelines for the next European Commission 2019-2014, https://www.europarl.europa.eu/resources/library/media/ 20190716RES57231/20190716RES57231.pdf (access 15.08.2019). 
gram is different from the main ideas presented by EPP leading candidate Manfred Weber ${ }^{29}$ and seems to give different weight to priorities of the EPP group. ${ }^{30}$ Among six priorities outlining the European Commission working programme for 2019-2024, there are issues addressing challenges presented by the alternative forces in the EP. The first priority is a nod towards the Greens, even though the party group voted against Ursula von der Leyen. Its priority concerns environmental protection actions in Europe, setting an ambitious goal of becoming the first climate-neutral continent. The pace of carbon emission reduction, proposed by the new Commission President, is in line with the Greens proposals ${ }^{31}$ and it also evokes many other measures present in the Greens programme, such as the European climate law and carbon border tax. Some other priorities of the New European Commission are consistent with the Greens, PES ${ }^{32}$ and EPP programmes as well - support for SMEs, social rights, diversity and gender equality. The last one became the hallmark of Ursula von der Leyen. Just after her nomination and election to the Commission President (she is the first woman in history to hold the post) she repeatedly announced that she would like to see the same number of men as women among European commissioners. ${ }^{33}$ The political guidelines of New European Commission, named $A$ Union of Equality, include a plan of foundation of new European Gender Strategy, built on the principle of equal pay for equal work and comprising anti-discrimination legislation, such as for example a directive on gender balance on company boards. A Union of Equality constitutes a part of the second set of goals for Europe proposed by the new President of European Commission, named An economy that works for people. In addition to gender equality issues, it also includes actions concerning SMEs support, deepening Economic and Monetary Union, implementing the European Pillar of Social Rights and fair taxa-

${ }_{29}$ M. Weber, Better Europe, My Ideas, https://weber.epp.eu/my_ideas?locale=en (access 15.08.2019).

${ }^{30}$ EPP Group, Our priorities, https://www.eppgroup.eu/what-we-stand-for/our-priorities (access 15.08.2019).

31 The Greens are calling for reducing carbon emissions by at least $55 \%$ by 2030 , and in her political program Ursula von der Leyer is mentioning increasing the EU's target for 2030 from 40\% towards 55\% emissions reduction; Priorities for 2019: What European Greens Fight For; https://europeangreens.eu/priorities-2019-what-european-greens-fight (access 15.08.2019).

${ }^{32}$ A New Social Contract for Europe. PES Manifesto 2019, https://www.pes.eu/export/ sites/default/.galleries/Documents-gallery/PES-Manifesto-2019_EN.pdf_2063069299. pdf (access 15.08.2019).

33 D.M. Herszenhorn, M. de la Baume, Ursula von der Leyen's narrowly won homecoming, "Politico", 17.07.2019, https:/www.politico.eu/article/ursula-von-der-leyens-european-commission-president-narrowly-won-homecoming/ (access 15.08.2019). 
tion. The fair taxation priority concerns mostly big tech companies and encompasses the EU actions on international and European solutions for a fair digital tax. In general, the digital age constitutes another challenge for the new European Commission. Therefore, a third area of the European Commission actions for 2019-2024 concerns adjustments to the changes caused by the digital age. It comprises such activities as standards definition for a new generation of technologies, European approach to the human and ethical implications of Artificial Intelligence, a new Digital Services Act and Digital Education Action Plan.

The fourth objective of the Commission's activities, Protecting our European way of life, refers both to the postulate of the established Europarties and alternative forces. At the outset, the importance of defending core European values and offering support to additional comprehensive European Rule of Law Mechanism were emphasized. The new President of the European Commission declared support for the proposal to make a rule of law an integral part of the next Multiannual Financial Framework. The second part of the fourth objective refers to postulates of European populist parties and concerns a New Pact on Migration and Asylum, a reinforcement of European Border and Coast Guard Agency and a modernization of a Common European Asylum System. A new opening in the area of illegal migration is to focus on European development cooperation on improving the perspectives of young people in their countries of origin via investment in health and education systems, infrastructure, sustainable growth and security.

Another sphere of the European Commission activity in the period 2019-2024 is to include actions strengthening Europe's position in the world mainly through standard settings of fair trade agreements. According to Ursula von der Leyen's declaration, every new trade agreement will have a part dedicated to sustainable-development and the highest standards of climate, environmental and labour protection. The statement is in line with fair-trade postulates formulated during elections by both established Europarties and alternative forces. Other planned actions in this area include a comprehensive strategy on Africa, the European perspective of Western Balkans and strategic partnership with the United Kingdom. Referring to Brexit, the new President of the European Commission stated that the negotiated Withdrawal Agreement was the best and only deal possible for an orderly withdrawal. The last element of the fifth priority $A$ Stronger Europe in the world concerns Europe's defence and increased efforts towards a genuine European Defence Union. One of activities in this area is to be the strengthening of the European Defence Fund to open up new opportunities for high-tech industries and other sectors of economy. 
The last priority presented in the Political Guidelines for the next European Commission, $A$ new push for European democracy, relates mainly to the role of the European Parliament in the legislation process. The new President of the European Commission declares strengthening the relationship with the European Parliament by responding with a legislative act on Parliament resolutions (acting by a majority of its members) requesting submission of legislative proposals. According to Ursula von der Leyen the European Parliament should have full co-decision power in areas such as climate, energy, social and taxation policies where unanimity currently applies. There is also a need of improvement of the lead candidate system. The proposed ideas should be discussed within the Conference on the Future of Europe that will start in 2020 and run for two years.

The political programme for the European Commission for 2019-2024 presented by Ursula von der Leyen to the European Parliament addresses most of the issues presented during the EP elections by the established Europarties and alternative forces. Therefore, it has a highly political nature, intended to win the support of many political groups. However, the political nature does not mean a poor prospect of its implementation. Its convergence with the European Council's New Strategic Agenda 2019$2024^{34}$ may facilitate its implementation, by introducing other weights to specific issues. The issue of migration and security, as well as economic issues are at the forefront in the New Strategic Agenda.

\section{Conclusions}

The EP elections resulted in a Parliament more diverse than ever. Two biggest party groups, the centre-right European People's and the centreleft Socialists and Democrats lost a significant number of seats and its forty-year domination in the EP. The loss was to some extent covered by the good performance of the liberals, a natural candidate for a coalition with the established Europarties. Alternative parties, especially the Greens and right-wing populists, also achieved good results in the elections, giving a signal to introduce changes in the current course of the process of European integration. The first modifications to this process were made shortly after the election by the European Council, when it appointed four important posts: the President of the Commission, the President of the Council, the President of the European Central Bank and

\footnotetext{
${ }^{34}$ A new strategic agenda 2019-2024, Press release, 20.06.2019; https://www.consilium.europa.eu/en/press/press-releases/2019/06/20/a-new-strategic-agenda-2019-2024/ (access 20.08.2019).
} 
the High Representative of the Union for Foreign Affairs and Security Policy. The omission of the Spitzenkandidaten process and the nomination of Ursula von der Leyen to the President of the European Commission aroused particular controversy in the EP. However, regardless of having the President of the Commission appointed either by the Parliament or the European Council, reaching majority support in the Parliament for Commission initiatives remains a challenge on a case-by-case basis. It may decrease the efficiency of the EP legislative process, but by opening up to more diverse participants of a political process, it may have a positive effect on EU-level democracy. ${ }^{35}$ The openness to various political forces and to main challenges of the current integration process is evident in the Political Guidelines for the next European Commission.

\section{References}

A New Social Contract for Europe. PES Manifesto 2019, https://www.pes. eu/export/sites/default/galleries/Documents-gallery/PES-Manifesto2019_EN.pdf_2063069299.pdf (access 15.08.2019).

A Union that strives for more. My agenda for Europe. By candidate for President of the European Commission Ursula von der Leyen. Political Guidelines for the next European Commission 2019-2014, https://www.europarl.europa. eu/resources/library/media/20190716RES57231/20190716RES57231. pdf (access 15.08.2019).

Barigazzi J. et al., Von der Leyen tapped to run European Commission, "Politico", 3.07.2019, https://www.politico.eu/article/eu-european-leaderspick-germany-defense-minister-ursula-von-der-leyen-to-lead-commission-charles-michel-council/ (access 2.08.2019).

Christiansen T., After the Spitzenkandidaten: fundamental change in the EU's political system? "West European Politics", June 2016, DOI: https://doi.org/10.1080/01402382.2016.1184414.

EPP Group, Our priorities, https://www.eppgroup.eu/what-we-stand-for/ our-priorities (access 15.08.2019).

A new strategic agenda 2019-2024, Press release, 20.06.2019, https://www. consilium.europa.eu/en/press/press-releases/2019/06/20/a-new-strategic-agenda-2019-2024/ (access 20.08.2019).

Fromage D., The 2019 European Parliament elections: Looking back and ahead, "Perspectives on Federalism", No. 11(1)/2019, pp. 94-101.

Funke M., Schularick M., Trebesch Ch., Going to extremes: Politics after financial crises, 1870-2014, "European Economic Review", No. 88/2016, pp. 227-260, DOI: https://doi.org/10.1016/j.euroecorev.2016.03.006.

\footnotetext{
${ }^{35}$ R.F. Inglehart, Modernization, Existential Security ..., op. cit.
} 
Hainmueller J., Hiscox M.J., Educated Preferences : Explaining Attitudes Toward Immigration in Europe, "International Organization", No. 61/2007, pp. 399-442.

Halla M., Wagner A.F., Zweimeuller J., Immigration and Voting for the Far Right, "Journal Ofthe European Economic Association", 15 (January)/ 2018, pp. 1341-1385, DOI: https://doi.org/10.1093/jeea/jvx003.

Herszenhorn D.M., de la Baume M., Ursula von der Leyen's narrowly won homecoming, "Politico", 17.07.2019, https://www.politico.eu/article/ursula-von-der-leyens-european-commission-president-narrowly-wonhomecoming/ (access 15.08.2019).

How different generations voted in the EU election, https://europeelects. eu/2019/06/03/how-different-generations-voted-in-the-eu-election/ (access 2.08.2019).

Inglehart R.F., Norris P., Trump, Brexit, and the Rise of Populism: Economic Have-Nots and Cultura Backlash, "HKS Faculty Research Working Paper Series", RWP 16-026, August 2016.

Inglehart R.F., Modernization, Existential Security, and Cultural Change: Reshaping Human Motivations and Society, in: Handbook of Advanced in Culture and Psychology, Vol. 7, eds. M.J. Gelfand, Chi-Yue Chiu, YindYi Hong, Oxford University Press, Oxford 2018.

Inglehart R.F., The Silent Revolution, Princeton University Press, Princeton, NJ 1977.

Leading academics on the European elections 2019, eds. N. Bolin, K. Falasca, M. Grusell, Nord L. Mittuniversitetet, Demicom, Sundsvall, Sverige 2019.

Manfred W., Better Europe, My Ideas, https://weber.epp.eu/my_ideas? locale $=$ en (access 15.08.2019).

Priorities for 2019: What European Greens Fight For, https://europeangreens. eu/priorities-2019-what-european-greens-fight (access 15.08.2019).

Rydgren J., The Sociology of the Radical Right, "The Annual Review of Sociology", No. 33/2007, pp. 241-261, DOI: https://doi.org/10.1146/annurev.soc.33.040406.131752.

Schminke T.G., How different generations voted in the EU election, 3.06.2019.

Schulmeister P., Büttner M., Chiesa A., Defourny E., Hallaouy S., Maggio L., Tsoulou-Malakoudi D., Eckhard M., Closer to the Citizens, Closer To The Ballot. Spring Eurobarometer 2019, Eurobarometer Survey 91.1 of the European Parliament. A Public Opinion Monitoring Study, April 2019-PE 637.932.

Shackleton M., The Election of the Commission President in 2014: What Does It Tell Us about Democracy in the European Union, "ISL Working Paper", No. 4/2014. 
Spring Eurobarometer 2019, Eurobarometer Survey 91.1 of the European Parliament. A Public Opinion Monitoring Study.

The European Parliament Elections of 2019, eds. L. De Sio, M. Franklin, L. Russo, Luiss University Press 2019.

Voss D., The Political Economy of European Populism: Labour Market Dualisation and Protest Voting in Germany and Spain, "LEQS Paper" No. 132/2018. 